\title{
Life Cycle Analysis on Fossil Energy Ratio of Algal Biodiesel: Effects of Nitrogen Deficiency and Oil Extraction Technology
}

\author{
Hou Jian, ${ }^{1,2}$ Yang Jing, ${ }^{2}$ and Zhang Peidong ${ }^{3}$ \\ ${ }^{1}$ South China Green Design RङD Center, China Quality Certification Center Guangzhou Branch, Guangzhou, \\ Guangdong 510620, China \\ ${ }^{2}$ Qingdao Institute of Bioenergy and Bioprocess Technology, Chinese Academy of Sciences, Qingdao, Shandong 266101, China \\ ${ }^{3}$ Qingdao University of Science \& Technology, Qingdao, Shandong 266042, China
}

Correspondence should be addressed to Hou Jian; houjian@qibebt.ac.cn

Received 29 July 2014; Accepted 4 November 2014

Academic Editor: Shun-Gui Zhou

Copyright (C) 2015 Hou Jian et al. This is an open access article distributed under the Creative Commons Attribution License, which permits unrestricted use, distribution, and reproduction in any medium, provided the original work is properly cited.

Life cycle assessment (LCA) has been widely used to analyze various pathways of biofuel preparation from "cradle to grave." Effects of nitrogen supply for algae cultivation and technology of algal oil extraction on life cycle fossil energy ratio of biodiesel are assessed in this study. Life cycle fossil energy ratio of Chlorella vulgaris based biodiesel is improved by growing algae under nitrogen-limited conditions, while the life cycle fossil energy ratio of biodiesel production from Phaeodactylum tricornutum grown with nitrogen deprivation decreases. Compared to extraction of oil from dried algae, extraction of lipid from wet algae with subcritical cosolvents achieves a $43.83 \%$ improvement in fossil energy ratio of algal biodiesel when oilcake drying is not considered. The outcome for sensitivity analysis indicates that the algal oil conversion rate and energy content of algae are found to have the greatest effects on the LCA results of algal biodiesel production, followed by utilization ratio of algal residue, energy demand for algae drying, capacity of water mixing, and productivity of algae.

\section{Introduction}

With the rapid growth of economy and energy consumption, petroleum resources are gradually depleted and environmental pollution is increasingly serious. It has become emergent to search for alternative energy especially in the field of traffic and to mitigate the environmental problems caused by fossil energy production and using. Biomass energy has the characteristics of renewable raw material and biological carbon sequestration. Development of bioenergy is considered as an effective way to solve energy shortage and improve environment.

Changes of land use and increased emission of greenhouse gases can be caused by production of transportation biofuels from terrestrial energy plants [1]. Using algae as a feedstock for biofuels has led to much excitement and initiative. Although algae based fuels are widely considered as clean energy, fossil energy input during production of biofuels from algae may still aggravate depletion of nonrenewable resources and pollution of environment [2]. It is very necessary to estimate the ratio of energy output to fossil energy consumption (fossil energy ratio) of algal biodiesel based on the concept of life cycle analysis.

Currently, several studies of life cycle analysis on algal biofuels have been carried out. Frank et al. [3], Yang et al. [4], and Clarens et al. $[5,6]$ have shown that fertilizer input contributes a lot to the overall life cycle fossil energy consumption and global warming of algal biofuel. Sander and Murthy [7] have shown that extraction of oil from dried algae results in high life cycle fossil energy input. With the increasing researches on mass culture of algae and algal oil extraction, several studies have assessed the life cycle fossil energy ratio of algal biofuels produced by new technologies. Life cycle assessment results of Lardon et al. [8] on algal biodiesel produced from Chlorella vulgaris with different nitrogen (N) supplies have shown that life cycle fossil energy ratio can be improved when algae grow under low $\mathrm{N}$ condition. Some researches show that the productivities, constituents, and calorific values 


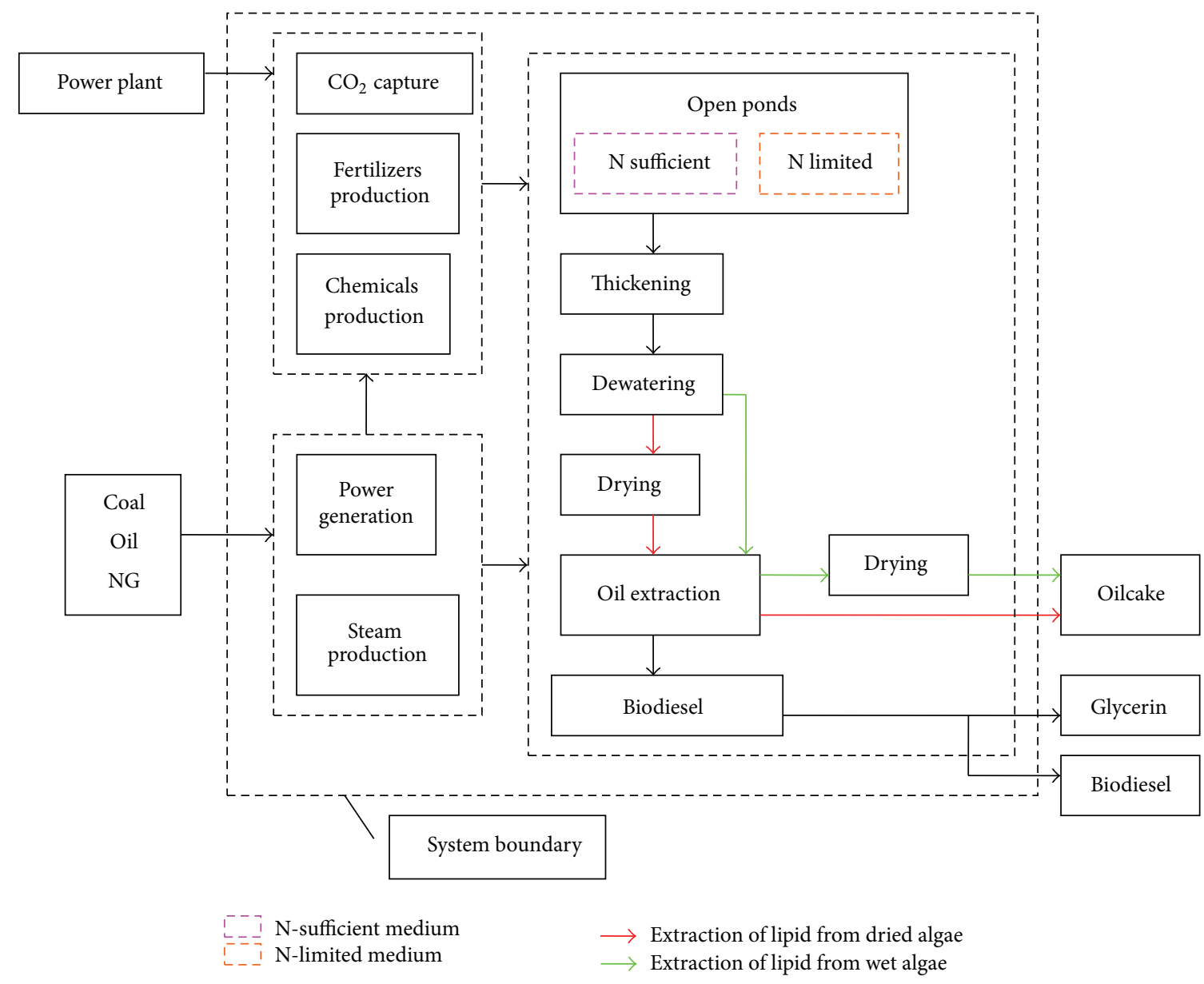

FIGURE 1: Life cycle system of biodiesel production from algae.

of different algae species may present different changing tendency when the $\mathrm{N}$ supply reduces [9-11]. Therefore, in order to identify whether life cycle fossil energy ratio of algal biodiesel can be promoted by low $\mathrm{N}$ condition, energy analysis of biodiesel based on different algae species should be carried out. Batan et al. [12] and Brentner et al. [13] compared the life cycle fossil energy use of algal biodiesel by extraction of oil from dried and wet algae. However, the energy consumption for extraction of oil from wet algae is hypothetical data, and reliability of the assessment results remains unknown.

It is thus clear that the existing LCA studies on algal biofuels contain several problems and this results in the fact that life cycle fossil energy ratio of algal biofuel cannot be scientifically identified based on the present research status. To fill up the deficiency above, with algal biodiesel as the objective of our study, we investigate the cell compositions and productivities of Phaeodactylum tricornutum and Chlorella vulgaris grown with sufficient and limited nitrogen supply. Studies on lipid extraction from wet algae may mainly concern extraction yields of algal oil but often neglect energy required for lipid extraction [14]. In this study, energy demands for extraction of oil from wet algae of pilot production are monitored. Effects of nitrogen supply conditions and algal oil extraction technologies on life cycle fossil energy ratio of algal biodiesel are assessed. To verify the reliability of our study, our results are compared with energy balance of other similar LCA studies on algal biofuel. A sensitivity analysis is performed to identify key parameters affecting life cycle fossil energy ratio of algal biodiesel.

\section{Methodologies}

2.1. Functional Unit. The functional unit for the LCA in this study is $1 \mathrm{MJ}$ biodiesel produced.

2.2. Life Cycle System Boundary of Algal Biodiesel. Figure 1 shows the simulated life cycle system of algal biodiesel production in this study. Algae are grown in open ponds with sufficient or limited nitrogen supply. $50 \%$ of the normal nitrogen supply is used in the $\mathrm{N}$-limited medium. Algae harvesting includes steps of concentration, dewatering, and drying [15]. The content of algal biomass in the fluid from cultivation ponds is lower than $5 \mathrm{wt} \%$. Concentration reduces the water content of the algal biomass from $99 \mathrm{wt} \%$ to $95 \mathrm{wt} \%$. Dewatering is needed to further decrease the water content to $60 \mathrm{wt} \%-80 \mathrm{wt} \%$. Algae have to be dried up to a $90 \mathrm{wt} \%$ solid content if the same technology as soybean lipid extraction is applied to extraction of oil from algae. 
Chen et al. [16] designed the extraction of oil from wet algae biomass with about $30 \mathrm{wt} \%$ solids. Biodiesel is obtained through transesterification reaction of algal lipid and methanol.

\subsection{Evaluation Model for Life Cycle Energy Efficiency of Algal Biodiesel}

2.3.1. Life Cycle Primary Energy Consumption Calculation. When $1 \mathrm{MJ}$ biodiesel is produced, the life cycle primary fossil energy demand $\left(\mathrm{EC}_{\mathrm{LC}}\right)$ is calculated as the sum of all the primary fossil energy consumptions due to production of all the process energy and materials directly used in all the substages according to the GREET model [17]:

$$
\mathrm{EC}_{\mathrm{LC}}=\sum_{i} \sum_{j} \mathrm{EE}_{i, j} \times \mathrm{PE}_{j}+\sum_{i} \sum_{n} M_{i, n} \times \mathrm{PE}_{n},
$$

where $\mathrm{EE}_{i, j}$ is the process energy $j$ consumption during substage $i(\mathrm{MJ}) ; \mathrm{PE}_{j}$ is the life cycle primary fossil energy use for process energy $j$ production $(\mathrm{MJ} / \mathrm{MJ}) ; M_{i, n}$ is the material $n$ consumption during substage $i(\mathrm{~kg}) ; \mathrm{PE}_{n}$ is the life cycle primary fossil energy use for material $n$ production $(\mathrm{kg} / \mathrm{MJ})$.

During algae cultivation, the power demand for mixing $\left(\mathrm{EE}_{\text {mixing }}\right)$ is computed using

$$
\begin{aligned}
\mathrm{EE}_{\text {mixing }} & =\frac{M_{\text {algae }} \times W_{\text {mixing }} \times t_{w} \times t_{r}}{C} \\
& =\frac{M_{\text {algae }} \times W_{\text {mixing }} \times t_{w}}{Y_{V}},
\end{aligned}
$$

where $M_{\text {algae }}$ is the algae consumption to produce $1 \mathrm{MJ}$ biodiesel $(\mathrm{kg}) ; W_{\text {mixing }}$ is the mixing capacity $\left(\mathrm{W} / \mathrm{m}^{3}\right) ; t_{w}$ is the working hours of mixing equipment per day $(\mathrm{h} / \mathrm{d}) ; t_{r}$ is the retention time of algae (d); $C$ is the algal biomass concentration $\left(\mathrm{kg} / \mathrm{m}^{3}\right) ; Y_{V}$ is the volumetric productivity $\left(\mathrm{kg} / \mathrm{m}^{3} \cdot \mathrm{d}\right)$.

The $M_{\text {algae }}$ and $Y_{V}$ are calculated using the following equations, respectively:

$$
\begin{aligned}
& M_{\text {algae }} \\
& =\frac{1}{\mathrm{HV}_{\text {biodiesel }} \times \eta_{\text {ester }} \times \eta_{\text {extra }} \times \eta_{\text {harve }} \times P_{\text {algae,oil }} \times P_{\text {nuetr oil }}} \\
& Y_{V}=Y_{A} \times \frac{A}{V}
\end{aligned}
$$

where $\mathrm{HV}_{\text {biodiesel }}$ is the net caloric value of biodiesel $(\mathrm{MJ} / \mathrm{kg})$; $\eta_{\text {harve }}, \eta_{\text {extra }}$, and $\eta_{\text {ester }}$ are the efficiencies of algae harvesting, algal oil extraction, and esterification, respectively (\%); $P_{\text {algae,oil }}$ is the total oil content of algae (\%); $P_{\text {nuetroil }}$ is the percentage of neutral oil in total oil (\%); $Y_{A}$ is the areal productivity $\left(\mathrm{kg} / \mathrm{m}^{2} \cdot \mathrm{d}\right) ; A / V$ is the ratio of illuminated area to volume $\left(\mathrm{m}^{-1}\right)$.
Power consumption for pumping ( $\left.\mathrm{EE}_{\text {pumping }}\right)$ is calculated using

$$
\begin{aligned}
\mathrm{EE}_{\text {pumping }}= & \frac{M_{\text {algae }} \times \rho_{\text {water }} \times g \times H}{C \times \eta_{\text {pump }}} \\
& \times\left(1+\lambda_{\text {water,evap }}+\lambda_{\text {lose }}\right),
\end{aligned}
$$

where $\rho_{\text {water }}$ is the density of water $\left(\mathrm{kg} / \mathrm{m}^{3}\right) ; g$ is the force of gravity $(\mathrm{N} / \mathrm{kg}) ; H$ is the liquid head $(\mathrm{m}) ; \eta_{\text {pump }}$ is the pumping efficiency (\%); $\lambda_{\text {water,evap }}$ and $\lambda_{\text {water,lose }}$ are water evaporation rate and water delivering loss rate, respectively (\%).

When $1 \mathrm{MJ}$ biodiesel is produced, consumptions of $\mathrm{CO}_{2}$ $\left(M_{\mathrm{CO}_{2}}\right)$ and fertilizer $\left(M_{\text {fertili }}\right)$ are calculated by using the following equations, respectively:

$$
\begin{gathered}
M_{\mathrm{CO}_{2}}=\frac{M_{\text {algae }} \times P_{\text {algae }, \mathrm{C}} \times 44 / 12}{\eta_{\text {fixing }}}, \\
M_{\text {ferti }}=M_{\text {algae }} \times P_{\text {algae }, \mathrm{N}(P)} \times\left(\lambda_{\mathrm{N}(P) \text {,evap }}+\eta_{\text {harve }}\right),
\end{gathered}
$$

where $P_{\text {algae,C }}$ is the carbon content of algae (\%); $\eta_{\text {fixing }}$ is the $\mathrm{CO}_{2}$ fixing efficiency of algae $(\%) ; P_{\text {algae, } N(P)}$ is the nitrogen or phosphorus content of algae (\%); $\lambda_{\mathrm{N}(P) \text {,evap }}$ is the nitrogen or phosphorus evaporation rate (\%).

2.3.2. Life Cycle Energy Output Calculation. The life cycle energy outputs are calculated based on the energy released from combustion of biodiesel, oilcake, and glycerin $[8,18]$ :

$$
\begin{gathered}
\mathrm{EP}_{\text {biodiesel }}=1, \\
\mathrm{EP}_{\text {oilcake }}=M_{\text {algae }} \times \mathrm{HV}_{\text {algae }}-\frac{1}{\eta_{\text {esterification }}}, \\
\mathrm{EP}_{\text {glycerin }}=M_{\text {glycerin }} \times \mathrm{HV}_{\text {glycerin }},
\end{gathered}
$$

where $\mathrm{EP}_{\text {biodiesel, }}, \mathrm{EP}_{\text {oilcake}}$, and $\mathrm{EP}_{\text {glycerin }}$ are the energy released from biodiesel, oilcake, and glycerin combustion, respectively $(\mathrm{MJ}) ; \mathrm{HV}_{\text {algae }}$ is the net caloric value of algae $(\mathrm{MJ} / \mathrm{kg}) ; M_{\text {glycerin }}$ is the glycerin output when $1 \mathrm{MJ}$ biodiesel is produced $(\mathrm{kg}) ; \mathrm{HV}_{\text {glycerin }}$ is the net caloric value of glycerin (MJ/kg).

$\mathrm{HV}_{\text {algae }}$ is calculated as

$$
\mathrm{HV}_{\text {algae }}=\sum_{i} P_{\text {algae }, n} \times \mathrm{HV}_{n},
$$

where $P_{\text {algae }, n}$ is the percentage of ingredient $n$ in algae (\%); $\mathrm{HV}_{n}$ is the net caloric value of ingredient $n(\mathrm{MJ} / \mathrm{kg})$.

2.3.3. Life Cycle Fossil Energy Ratio Calculation. The life cycle fossil energy ratio of biodiesel production $\left(\eta_{\text {fossil }}\right)$ is the ratio of the life cycle energy output to the life cycle primary fossil energy consumption:

$$
\eta_{\mathrm{fossil}}=\frac{\sum_{m} \mathrm{EP}_{m}}{\sum_{i} \mathrm{EC}_{i}} \times 100 \%,
$$

where $\mathrm{EP}_{m}$ is the energy output $m(\mathrm{MJ}) ; \mathrm{EC}_{i}$ is the primary energy consumption in substage $i(\mathrm{MJ})$. 
TABle 1: Productivity and cell composition of algae grown under N-sufficient and N-limited conditions.

\begin{tabular}{|c|c|c|c|c|c|c|c|c|}
\hline \multirow[b]{2}{*}{ Strains } & \multicolumn{4}{|c|}{ Normal N supply } & \multicolumn{4}{|c|}{ Limited N supply ( $50 \%$ of normal N supply) } \\
\hline & Protein $/ \%$ & Carbonhydrate/\% & Lipid/\% & $\begin{array}{l}\text { Productivity/ } \\
\mathrm{g} / \mathrm{m}^{2} \cdot \mathrm{d}\end{array}$ & Protein $/ \%$ & Carbonhydrate/\% & Lipid/\% & $\begin{array}{l}\text { Productivity/ } \\
\mathrm{g} / \mathrm{m}^{2} \cdot \mathrm{d}\end{array}$ \\
\hline $\begin{array}{l}\text { Phaeodactylum } \\
\text { tricornutum }^{\mathrm{b}}\end{array}$ & 32.2 & 18.5 & 28.46 & 25 & 24.76 & 16.7 & 31.8 & 15.45 \\
\hline Chlorella vulgaris $^{\mathrm{c}}$ & 31 & 51 & 18 & 22 & 6 & 54 & 40 & 19.85 \\
\hline
\end{tabular}

${ }^{\mathrm{b}}$ Source: $[9,21] .{ }^{\mathrm{c}}$ Source: $[11,22]$.

TABLE 2: $\mathrm{CO}_{2}$ fixing efficiencies of different algae species.

\begin{tabular}{lcc}
\hline & $\begin{array}{c}\text { Phaeodactylum } \\
\text { tricornutum }\end{array}$ & Chlorella vulgaris \\
\hline $\mathrm{CO}_{2}$ fixing efficiency/\% & $64.9^{\mathrm{f}}$ & $60^{\mathrm{g}}$ \\
\hline${ }^{\mathrm{f}}$ Source: [23]. ${ }^{\mathrm{g}}$ Source: $[24]$. & &
\end{tabular}

\section{Data Collection}

Under conditions with sufficient and limited nitrogen supply, the algal productivities and cell compositions of Phaeodactylum tricornutum and Chlorella vulgaris grown in open ponds are shown in Table 1 . The chemical formulas and net caloric values of carbonhydrate, protein, and lipid are according to Lardon et al. [8]. Phosphorus content of algae is $1 \mathrm{wt} \%$ [19]. Algae concentration is $0.5 \mathrm{~g} / \mathrm{L}$ and pond height is $0.2 \mathrm{~m}$. According to Fagerstone et al. [20], when algae are cultivated in open ponds, the cumulative $\mathrm{N}_{2} \mathrm{O}$ emissions over the light and dark periods are $1.53 \times 10^{-5} \mathrm{~kg}$ and $6.51 \times 10^{-6} \mathrm{~kg}$ per $\mathrm{kg} \mathrm{N}$ input, respectively. When the concentration of $\mathrm{CO}_{2}$ injected to algae cultivation ponds is $5 \%, \mathrm{CO}_{2}$ fixing efficiencies of different algae species have been shown in Table 2.

According to the base data in Tables 1 and 2 and formulas of (6) and (9), the calculated nitrogen fertilizer inputs and heat values of algae under conditions of normal and limited $\mathrm{N}$ supply are shown in Table 3 . As Tables 1 and 3 show, under low $\mathrm{N}$ condition, lipid content of Chlorella vulgaris increases and algae productivity drops; nitrogen fertilizer and heat value of Phaeodactylum tricornutum both decrease.

Operation capacity of paddle wheel and aeration in open ponds is $3.72 \mathrm{~W} / \mathrm{m}^{3}$ [25]. It is assumed that working time of mixing equipment is $12 \mathrm{~h}$ per day. Average delivery head of centrifugal pump is $7.5 \mathrm{~m}$ with efficiency of $70 \%$ [15]. Water evaporation rate during algae cultivation is $10 \%$ [6] and water delivering loss is $5 \%$ [3].

Energy consumed in algae harvesting is from literature [26]. Dissolved air flotation is used for algae concentration with an electricity requirement of $100 \mathrm{kWh} / \mathrm{t}$ dry mass. The electricity demand of centrifuge for algae dewatering is $37 \mathrm{kWh} / \mathrm{t}$ dry mass. The energy demand for thermal drying of algae to $10 \%$ water content is $615.6 \mathrm{kWh} / \mathrm{t}$ dry mass. $10 \mathrm{wt} \%$ and $5 \mathrm{wt} \%$ of the algal cells are lost in concentration and dewatering, respectively [27].

Energy demands for extraction of oil from dried and wet algae are listed in Table 4 . It is assumed that the percentage of neutral lipid in total lipid of algae is $80 \%$. Energy requirements for oil refining are according to literature [28]. Energy consumptions in oil conversion stage are from literature [29]; the conversion efficiency is $96.5 \%$ and the net calorific value of biodiesel is $37.2 \mathrm{MJ} / \mathrm{kg}$.

It is assumed that electricity and steam consumed in the assessed system are generated from coal in China. The fertilizers and chemicals are produced using technologies on world average level and the energy demands for fertilizers and chemicals production are from Gabi database [31]. $\mathrm{CO}_{2}$ applied to algae growth is assumed to be from flue gas discharged from power plant. Flue gas from power or steel plant generally contains substances like sulfur oxide, nitric oxide, and heavy metals which are deleterious to algae growth. $\mathrm{CO}_{2}$ needs to be separated from the flue gas before it is injected into algae cultivation ponds. Membrane separation of $\mathrm{CO}_{2}$ is used with steam demands of $73 \mathrm{kWh}$ per ton of recovered $\mathrm{CO}_{2}$ and a capture efficiency of $85 \%$ [32]. $\mathrm{CO}_{2}$ capture not only provides nutrients for algae growth but also has been required in most coal-fired power stations. Energy demands for carbon capture are allocated between the power plant and the algae farm on an energy basis.

\section{Results}

4.1. Energy Efficiency Comparison Analysis of Biodiesel Production from Algae Grown with Normal and Limited Nitrogen Supply. With open ponds cultivation of algae, chemical absorption of $\mathrm{CO}_{2}$, and extraction of oil from dried algae, the calculated life cycle energy production and fossil energy consumed for Phaeodactylum tricornutum and Chlorella vulgaris based biodiesel with different nitrogen supplies are shown in Figures 2 and 4, and life cycle fossil energy ratios are shown in Figures 3 and 5.

It can be seen from Figure 2 that, under limited nitrogen supply condition, fossil energy consumption for harvesting and oil extraction of Phaeodactylum tricornutum and energy production of algae biomass all decrease. This is mainly due to the fact that oil content of Phaeodactylum tricornutum increases under low $\mathrm{N}$ condition and less algae input for 1 functional unit of biodiesel production is required. However, for the productivity and heat value of Phaeodactylum tricornutum both decrease under low $\mathrm{N}$ condition, the decline rate of energy production of algal biomass (11.06\%) is higher than that of the energy required in algae harvesting and oil extraction (10.64\%), and energy consumption for mixing 
TABLE 3: Net calorific values of algae and $\mathrm{N}$ fertilizer inputs.

\begin{tabular}{|c|c|c|c|}
\hline Species of algae & Heat values and nitrogen contents & Normal N & Low $\mathrm{N}$ \\
\hline \multirow{2}{*}{ Phaeodactylum tricornutum } & Heat value $(\mathrm{MJ} / \mathrm{kg})$ & 18.3 & 18.19 \\
\hline & $\mathrm{N}$ content $(\mathrm{kg} / \mathrm{kg})$ & 0.052 & 0.040 \\
\hline \multirow{2}{*}{ Chlorella vulgaris } & Heat value $(\mathrm{MJ} / \mathrm{kg})$ & 18.33 & 23.27 \\
\hline & $\mathrm{N}$ content $(\mathrm{kg} / \mathrm{kg})$ & 0.050 & 0.010 \\
\hline
\end{tabular}

TABLE 4: Energy consumptions and efficiency for algal oil extraction.

\begin{tabular}{lcc}
\hline & $\begin{array}{c}\text { Extraction from dried } \\
\text { algae }^{\mathrm{i}}\end{array}$ & $\begin{array}{c}\text { Extraction from wet } \\
\text { algae }^{\mathrm{j}}\end{array}$ \\
\hline Power $(\mathrm{kWh} / \mathrm{t}$ algae $)$ & 25 & 26.46 \\
Steam $(\mathrm{MJ} / \mathrm{t}$ algae $)$ & 1170.8 & 1239.01 \\
Efficiency $(\%)$ & 97.5 & 90 \\
\hline
\end{tabular}

${ }^{\mathrm{i}}$ The energy demands for extraction of oil from dried algae are from SEPA (State Environmental Protection Administration of China) of China [30]. ${ }^{\mathrm{j}}$ The energy demands for extraction of oil wet algae are based on a pilot-scale operation of algal oil extraction plant in China.

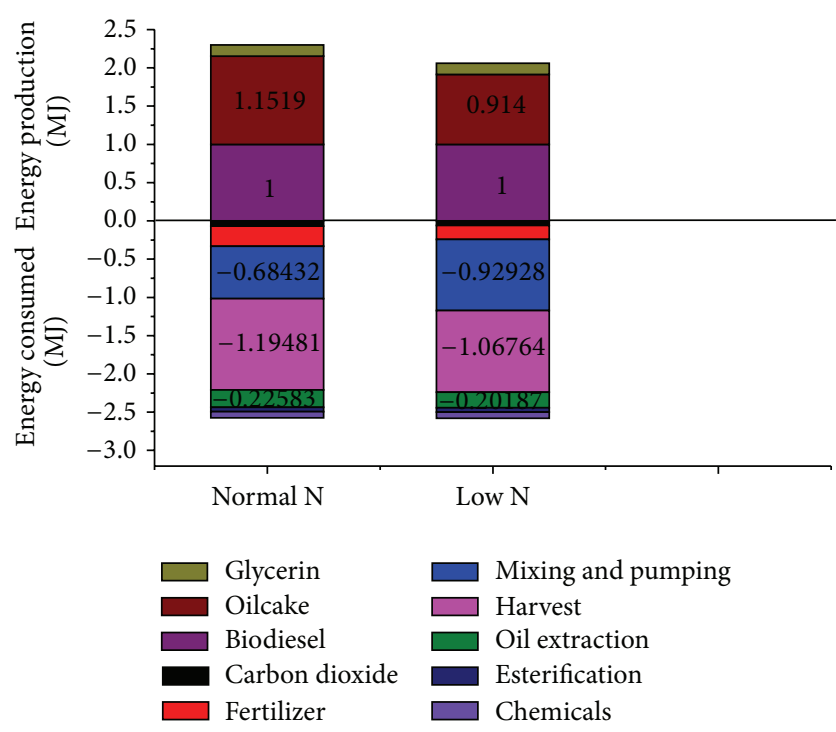

Figure 2: Phaeodactylum tricornutum. Energy losses and gains for the production of biodiesel from Phaeodactylum tricornutum grown in $\mathrm{N}$-sufficient and $\mathrm{N}$-limited mediums.

of cultivation water increases by $35.8 \%$. As a result, life cycle fossil energy ratio for Phaeodactylum tricornutum based biodiesel with limited nitrogen supply decreases by $10.56 \%$ compared with normal nitrogen supply (Figure 3).

As can be seen from Figure 4, under limited nitrogen supply condition, energy consumption for harvesting and oil extraction of Chlorella vulgaris decreases by $54.85 \%$ because of higher lipid content compared to normal nitrogen supply. Due to the heat value of Chlorella vulgaris increase under low $\mathrm{N}$ condition, the total energy production of biodiesel

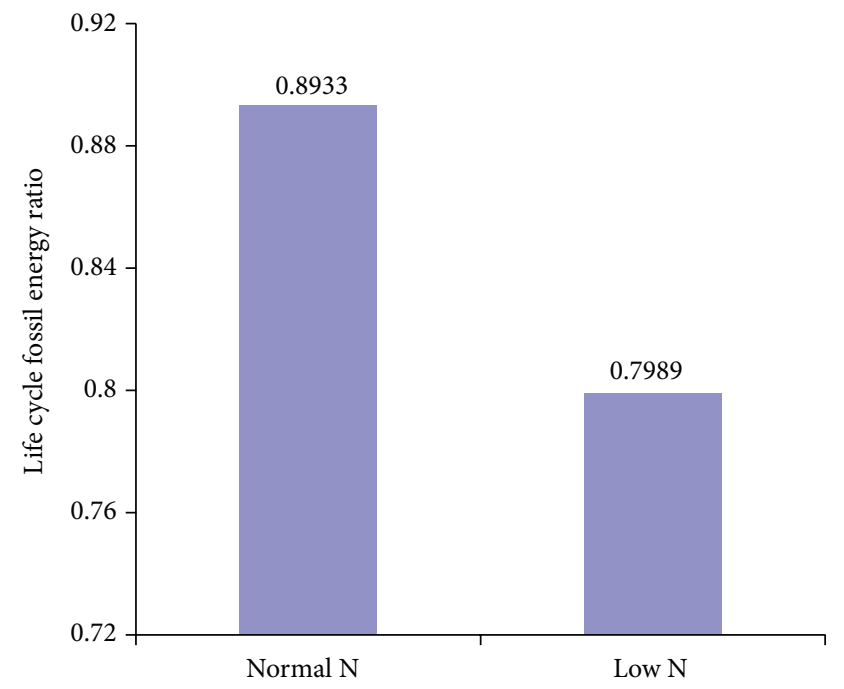

FIgURE 3: Life cycle fossil energy ratio for the production of biodiesel from Phaeodactylum tricornutum grown in normal and limited nitrogen supply conditions.

and oilcake only decreased by $14.09 \%$. As a result, life cycle fossil energy ratio for Chlorella vulgaris based biodiesel under limited nitrogen supply increases by $30.78 \%$ compared with normal nitrogen supply (Figure 5).

4.2. Energy Efficiency Comparison Analysis of Biodiesel Production from Oil Extracted from Dried and Wet Algae. The calculated life cycle energy outputs and fossil energy consumed for algal biodiesel produced from Chlorella vulgaris under low $\mathrm{N}$ condition in open ponds, with $\mathrm{CO}_{2}$ from membrane separation, and oil extracted from dried and wet algae are shown in Figure 6, and life cycle fossil energy ratios are shown in Figure 7.

As can be seen from Figure 6, compared to extraction of oil from dried algae, the energy consumed for extraction of oil from wet algae with subcritical cosolvents increases by $14.79 \%$ compared to extraction of oil from dried algae, and energy required for mixing increases by $8.1 \%$. This is mainly due to the fact that efficiency for oil extraction from wet algae is lower than from dried algae and more algae input for 1 functional unit of biodiesel production is required. However, algae drying process omitted makes lipid extraction from wet algae perform a $43.83 \%$ improvement in the life cycle fossil energy ratio of algal biodiesel compared to extraction of oil from dried algae (Figure 7). 


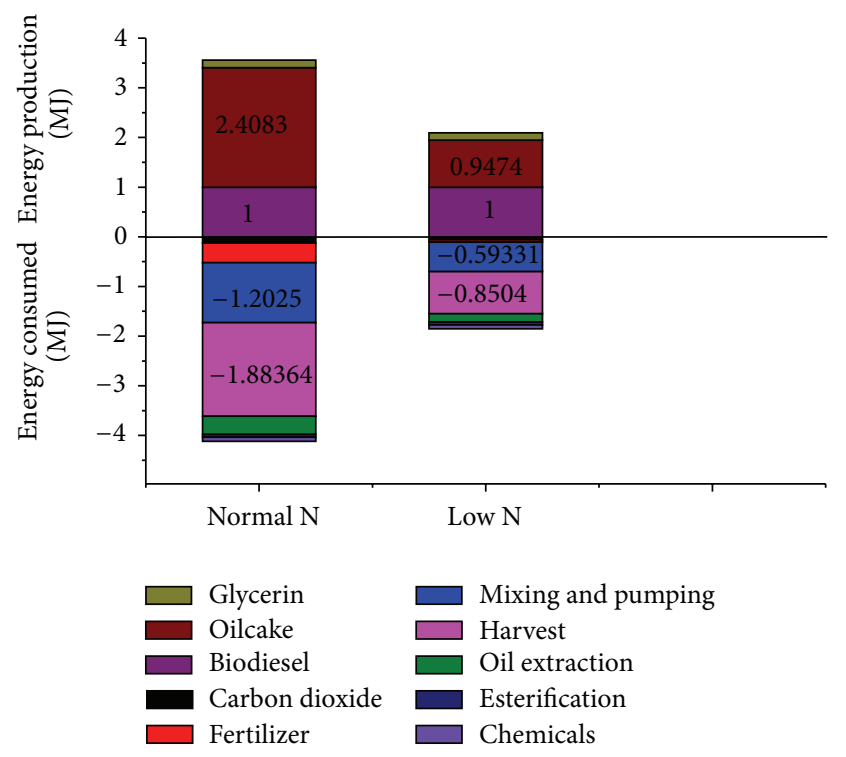

FIGURE 4: Chlorella vulgaris. Energy losses and gains for the production of biodiesel from Chlorella vulgaris grown in $\mathrm{N}$-sufficient and $\mathrm{N}$-limited mediums.

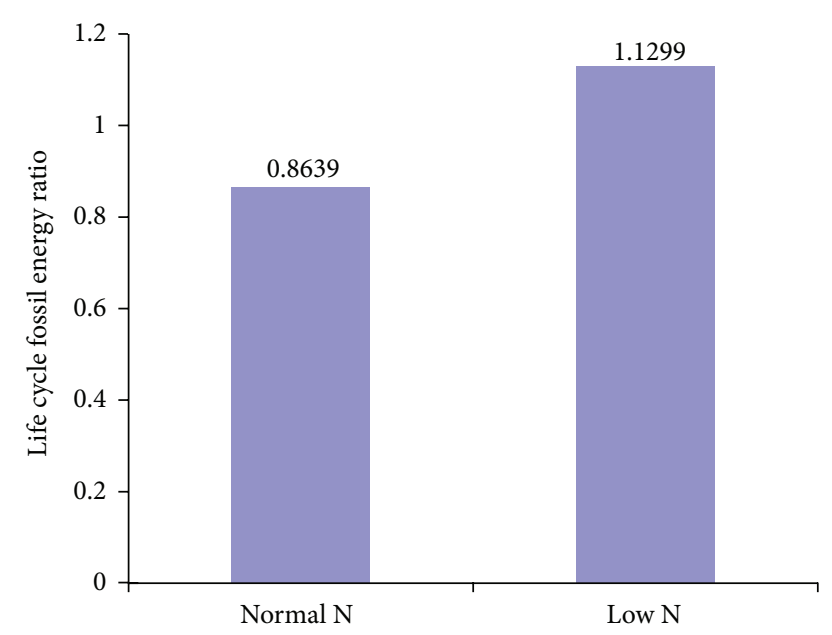

FIGURE 5: Life cycle fossil energy ratio for the production of biodiesel from Chlorella vulgaris grown in normal and limited nitrogen supply conditions.

4.3. Comparison of the Results with Other LCA Studies of Algal Biodiesel. This section has the goal of comparing the results of this study with other similar LCA studies on algal biodiesel and then analyzing the main differences among values for the life cycle fossil energy ratios in different studies. Values of energy demands, energy outputs, and life cycle fossil energy ratios of algae based biodiesel production from two literatures have been collected and are compared in Table 5 .

As can be seen from Table 5, when algal biodiesel made from similar pathways is taken as the research object, life cycle fossil energy ratio of biodiesel produced from dried algae is $66.18 \%$ higher in this study than in Lardon et al's study, and

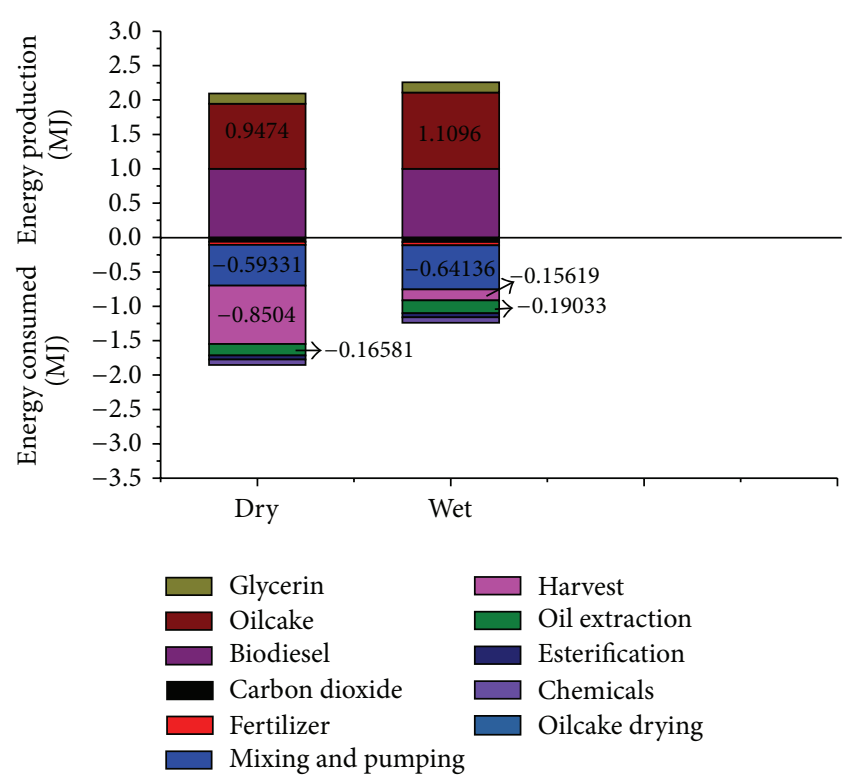

FIGURE 6: Energy input and output of biodiesel production using oil extracted from dried and wet algae.

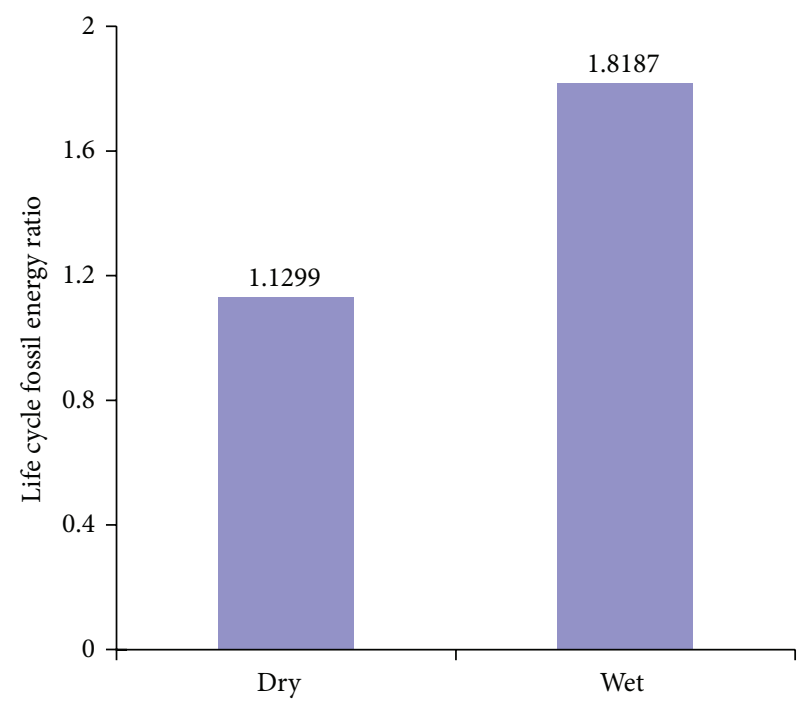

FIGURE 7: Life cycle fossil energy ratio for the production of biodiesel from algal oil extracted from dried and wet algae.

life cycle fossil energy ratio of biodiesel produced from wet algae is $35.82 \%, 355 \%$, and $28.57 \%$ higher in this study than in studies of Lardon et al., Razon and Tan [31], and Batan et al., respectively.

High energy consumption caused by backward algae drying technology is the main reason for the lower life cycle fossil energy ratio of biodiesel produced from dried algae in Lardon et al's study. Compared to energy consumption data of algae drying in the study of Zhao and Hu in 2009 on energy consumption of sludge treatment in wastewater treatment plant, energy consumption data of algae drying in study of Lardon et al. is from experimental study of Hassebrauck et al. 
TABLE 5: The primary energy demands, energy outputs, and life cycle fossil energy ratios for algal biodiesel production in different researches.

\begin{tabular}{|c|c|c|c|c|c|c|}
\hline \multirow{2}{*}{ Oil extraction technology } & \multicolumn{2}{|c|}{ This study } & \multicolumn{2}{|c|}{ Lardon et al., 2009 [8] } & \multirow{2}{*}{$\begin{array}{c}\text { Yang et al., } 2014 \text { [14] } \\
\text { Wet }\end{array}$} & \multirow{2}{*}{$\begin{array}{c}\text { Batan et al., } 2010[12] \\
\text { Wet }\end{array}$} \\
\hline & Dry & Wet & Dry & Wet & & \\
\hline \multicolumn{7}{|l|}{ Basic condition } \\
\hline Oil content/\% & \multicolumn{2}{|c|}{40} & \multicolumn{2}{|c|}{40} & 24 & 50 \\
\hline Productivity $/ \mathrm{g} / \mathrm{m}^{2} \cdot \mathrm{d}$ & \multicolumn{2}{|c|}{19.85} & \multicolumn{2}{|c|}{19.25} & 16 & 24.9 \\
\hline \multicolumn{7}{|l|}{ Primary fossil energy consumption/MJ } \\
\hline Cultivation & 0.65 & 0.71 & 0.41 & 0.59 & 2.246 & 0.73 \\
\hline Concentration & 0.11 & 0.11 & - & - & 0.103 & - \\
\hline Dewatering & 0.04 & 0.04 & - & - & - & 0.17 \\
\hline Drying & 0.7 & - & 1.39 & - & - & - \\
\hline Oil extraction & 0.17 & 0.19 & 0.14 & 0.52 & 1.895 & 0.21 \\
\hline Esterification & 0.06 & 0.06 & 0.03 & 0.03 & - & 0.17 \\
\hline Fertilizer production & 0.05 & 0.05 & 0.08 & 0.11 & 1.041 & - \\
\hline Chemicals production & 0.08 & 0.08 & 0.27 & 0.43 & 0.443 & - \\
\hline Biogas generation & - & - & - & - & 0.089 & - \\
\hline Sewage treatment & - & - & - & - & 0.884 & - \\
\hline \multicolumn{7}{|l|}{ Energy production/MJ } \\
\hline Biodiesel & 1 & 1 & 1 & 1 & 1 & 1 \\
\hline Oilcake & 0.9474 & 1.1096 & 0.57 & 1.23 & - & 0.79 \\
\hline Glycerin & 0.1474 & 0.1474 & - & - & 0.565 & - \\
\hline Credit for "fresh" water & - & - & - & - & 0.162 & - \\
\hline Biogas & - & - & - & - & 1.378 & - \\
\hline Credit for ammonium compounds & - & - & - & - & 0.027 & - \\
\hline Life cycle fossil energy ratio & 1.13 & 1.82 & 0.68 & 1.34 & 0.4 & 1.4 \\
\hline
\end{tabular}

in 1996 on sludge drying by belt dryer and its energy consumption for algae drying is about 2 times higher than results in study of Zhao and $\mathrm{Hu}[26]$. So timeliness of basic data has important effects on the validity of LCA results of algal biodiesel. Compared to energy consumption data of extraction of oil from wet algae in this study based on pilotscale study of Chen et al., Lardon et al. [8] and Batan et al. [12] calculated the energy consumption for extraction of oil from wet algae based on hypothesis and both of their results are higher than the energy consumed for extraction of oil from wet algae with subcritical cosolvents in study of Sturm and Lamer [15].

In study of Yang et al. [14], complicated algae cultivation process and low yield of algae lead to the high energy input during stages of algae cultivation and oil extraction. It makes algal biodiesel not able to deliver more energy than is required to produce it.

4.4. Sensitivity Analysis. A sensitivity analysis is performed to determine key parameters affecting the life cycle fossil energy ratio of algal biodiesel (see Figure 8 ). All parameters analyzed vary over equal confidence intervals. The effects of different parameters will be ranked by the change in the life cycle fossil energy ratio of algal biodiesel. Algal biodiesel produced from Chlorella vulgaris under low $\mathrm{N}$ condition in open ponds, with $\mathrm{CO}_{2}$ from membrane separation, and oil extracted from dried

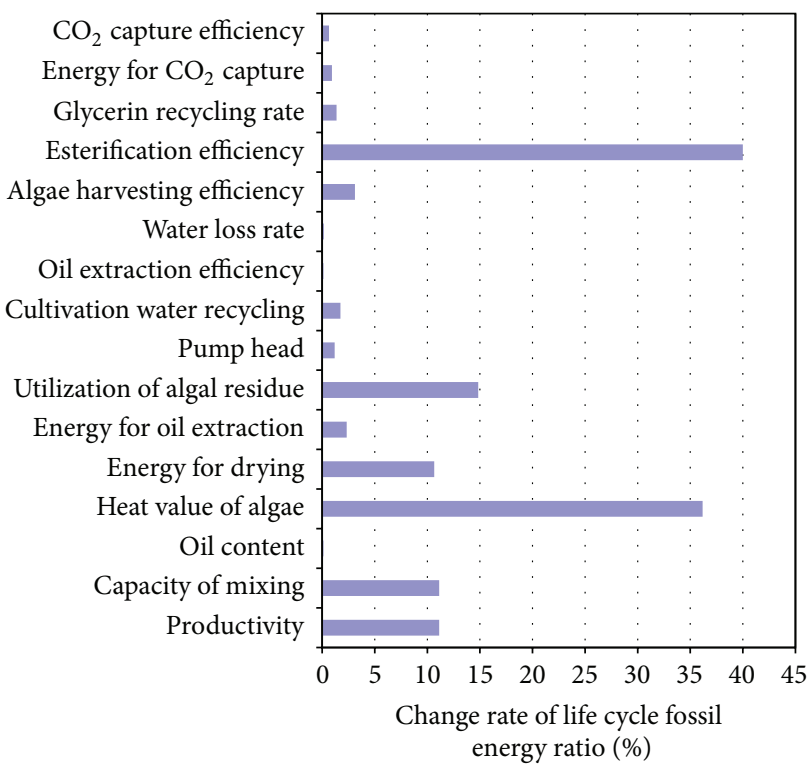

FIGURE 8: Sensitivity analysis of effects of several parameters on life cycle fossil energy ratio of algae biodiesel.

algae have been taken as the baseline scenario. The change rate of all uncertain parameters is $40 \%$. 
As can be seen from Figure 8, the changes of esterification efficiency and heat value of algae are found to have the greatest effects on the life cycle fossil energy ratio of algal biodiesel. As esterification efficiency and heat value of algae decrease by $40 \%$, the life cycle fossil energy ratio of algal biodiesel changes by $40 \%$ and $36.17 \%$, respectively. The second important parameters are utilization ratio of algal residue, algae cultivation water recycling rate, energy demand for algae drying, capacity of mixing, and productivity of algae and when those parameters separately decrease by $40 \%$, the life cycle fossil energy ratio of algal biodiesel changes between 10 and $15 \%$. When algal oil content, oil extraction energy consumption, pump head, cultivation water recycling rate, oil extraction efficiency, cultivation water loss, algae harvesting efficiency, glycerin recycling rate, $\mathrm{CO}_{2}$ capture energy consumption, and $\mathrm{CO}_{2}$ capture efficiency separately decrease by $40 \%$, the life cycle fossil energy ratio of algal biodiesel changes under $5 \%$.

\section{Conclusions}

(1) Nitrogen deficiency can not only promote the oil content of many species of algae but also decrease the productivity of algae. The change of algae cell composition has certain effects on its energy output. Life cycle fossil energy ratio of biodiesel produced from Chlorella vulgaris grown under nitrogen-limited conditions increases by $30.78 \%$. Life cycle fossil energy ratio of biodiesel produced from Phaeodactylum tricornutum grown with nitrogen deprivation decreases by $10.56 \%$.

(2) Compared to extraction of oil from dried algae, extraction of oil directly from wet algae with subcritical cosolvents can effectively promote the life cycle fossil energy ratio of algal biodiesel.

(3) Comparison of the results with other LCA studies of algal biodiesel shows that, when algal biodiesel made from similar pathways is taken as the research object, life cycle fossil energy ratio of biodiesel produced from dried algae is $66.18 \%$ higher in this study than in Lardon et al.s. Worse timeliness of data source for energy consumption of algae drying is the main reason. Life cycle fossil energy ratio of biodiesel produced from wet algae is $35.82 \%$ and $28.57 \%$ higher in this study than in the studies of Lardon et al. and Batan et al., respectively. Compared to Lardon et al. [8] and Batan et al. [12]'s calculation of the energy consumption for extraction of oil from wet algae based on hypothesis, energy consumption data of extraction of oil from wet algae in this study is based on pilot-scale study of Chen et al. So the results are more reliable.

(4) The changes of esterification efficiency and heat value of algae have the greatest effects on the life cycle fossil energy ratio of algal biodiesel, followed by utilization ratio of algal residue, algae cultivation water recycling rate, energy demand for algae drying, capacity of mixing, and productivity of algae. When esterification efficiency and heat value of algae decrease by $40 \%$, the life cycle fossil energy ratio of algal biodiesel changes by $40 \%$ and $36.17 \%$, respectively.

\section{Conflict of Interests}

The authors declare that there is no conflict of interests regarding the publication of this paper.

\section{References}

[1] J. Fargione, J. Hill, D. Tilman, S. Polasky, and P. Hawthorne, "Land clearing and the biofuel carbon debt," Science, vol. 319, no. 5867, pp. 1235-1238, 2008.

[2] A. Darzins, P. Pienkos, and L. Edye, Algae as a Feedstock for Biofuels: An Assessment of the Current Status and Potential for Algal Biofuels Production, IEA, 2011.

[3] E. D. Frank, J. Han, I. Palou-Rivera, A. Elgowainy, and M. Q. Wang, Life-Cycle Analysis of Algal Lipid Fuels with the GREET Model, Argonne National Laboratory, Lemont, Ill, USA, 2011.

[4] J. Yang, M. Xu, X. Zhang et al., "Life-cycle analysis on biodiesel production from microalgae: water footprint and nutrients balance," Bioresource Technology, vol. 102, pp. 159-165, 2011.

[5] A. F. Clarens, E. P. Resurreccion, M. A. White, and L. M. Colosi, "Environmental life cycle comparison of algae to other bioenergy feedstocks," Environmental Science and Technology, vol. 44, no. 5, pp. 1813-1819, 2010.

[6] A. F. Clarens, H. Nassau, E. P. Resurreccion, M. A. White, and L. M. Colosi, "Environmental impacts of algae-derived biodiesel and bioelectricity for transportation," Environmental Science and Technology, vol. 45, no. 17, pp. 7554-7560, 2011.

[7] K. Sander and G. S. Murthy, "Life cycle analysis of algae biodiesel," International Journal of Life Cycle Assessment, vol. 15, no. 7, pp. 704-714, 2010.

[8] L. Lardon, A. Helias, B. Sialve, J. P. Steyer, and O. Bernard, "Lifecycle assessment of biodiesel production from microalgae," Environmental Science and Technology, vol. 43, no. 17, pp. 64756481, 2009.

[9] Q. KaiXian and M. A. Borowitzka, "Light and nitrogen deficiency effects on the growth and composition of Phaeodactylum tricornutum," Applied Biochemistry and Biotechnology, vol. 38, no. 1-2, pp. 93-103, 1993.

[10] L. Uslu, O. Işik, K. Koç, and T. Göksan, "The effects of nitrogen deficiencies on the lipid and protein contents of Spirulina platensis," African Journal of Biotechnology, vol. 10, no. 3, pp. 386389, 2011.

[11] A. M. Illman, A. H. Scragg, and S. W. Shales, "Increase in Chlorella strains calorific values when grown in low nitrogen medium," Enzyme and Microbial Technology, vol. 27, no. 8, pp. 631-635, 2000.

[12] L. Batan, J. Quinn, B. Willson, and T. Bradley, "Net energy and greenhouse gas emission evaluation of biodiesel derived from microalgae," Environmental Science and Technology, vol. 44, no. 20, pp. 7975-7980, 2010.

[13] L. B. Brentner, M. J. Eckelman, and J. B. Zimmerman, "Combinatorial life cycle assessment to inform process design of industrial production of algal biodiesel," Environmental Science and Technology, vol. 45, no. 16, pp. 7060-7067, 2011.

[14] F. Yang, W. Xiang, X. Sun, H. Wu, T. Li, and L. Long, "A novel lipid extraction method from wet microalga Picochlorum sp. at room temperature," Marine Drugs, vol. 12, no. 3, pp. 1258-1270, 2014.

[15] B. S. M. Sturm and S. L. Lamer, "An energy evaluation of coupling nutrient removal from wastewater with algal biomass production," Applied Energy, vol. 88, no. 10, pp. 3499-3506, 2011. 
[16] M. Chen, T. Liu, X. Chen et al., "Subcritical co-solvents extraction of lipid from wet microalgae pastes of Nannochloropsis sp," European Journal of Lipid Science and Technology, vol. 114, no. 2, pp. 205-212, 2012.

[17] A. Burnham, M. Wang, and Y. Wu, GREET 2.8 Transportation Vehicle-Cycle Model, Argonne National Laboratory, Lemont, Ill, USA, 2008.

[18] L. F. Razon and R. R. Tan, "Net energy analysis of the production of biodiesel and biogas from the microalgae: Haematococcus pluvialis and Nannochloropsis," Applied Energy, vol. 88, no. 10, pp. 3507-3514, 2011.

[19] A. C. Redfield, "The biological contral of chemical factors in the environment," American Scientist, vol. 46, pp. 205-221, 1958.

[20] K. D. Fagerstone, J. C. Quinn, T. H. Bradley, S. K. de Long, and A. J. Marchese, "Quantitative measurement of direct nitrous oxide emissions from microalgae cultivation," Environmental Science \& Technology, vol. 45, no. 21, pp. 9449-9456, 2011.

[21] Solar Energy Research Institute (SERI), Microalgae Culture Collection 1986-1987, SERI Microlagal Technology Research Group, US, 1986.

[22] L. Boersma, E. W. R. Barlow, J. R. Miner, H. K. Phinney, and J. E. Oldfield, The Use of Waste Heat in a System for Animal Waste Conversion with By-product Recovery and Recycling, Oregon State University, 1975.

[23] F. G. Acién Fernández, C. Brindley Alías, M. C. García-Malea López et al., "Assessment of the production of 13C labeled compounds from phototrophic microalgae at laboratory scale," Biomolecular Engineering, vol. 20, no. 4-6, pp. 149-162, 2003.

[24] S. Van Den Hende, H. Vervaeren, S. Desmet, and N. Boon, "Bioflocculation of microalgae and bacteria combined with flue gas to improve sewage treatment," New Biotechnology, vol. 29, no. 1, pp. 23-31, 2011.

[25] O. Jorquera, A. Kiperstok, E. A. Sales, M. Embiruçu, and M. L. Ghirardi, "Comparative energy life-cycle analyses of microalgal biomass production in open ponds and photobioreactors," Bioresource Technology, vol. 101, no. 4, pp. 1406-1413, 2010.

[26] Q. Zhao and K. Hu, "Energy-use analysis of sludge processing in wastewater treatment plant," Water and Wastewater Information, vol. 4, pp. 15-20, 2009 (Chinese).

[27] R. W. Harris, M. J. Cullinane, and P. T. Sun, Process Design and Cost Estimating Algorithms for the Computer Assisted Procedure for Design and Evaluation of Wastewater Treatment Systems (CAPDET), US Environmental Protection Agency, 1982.

[28] X. Song and J. Yu, "Study on cost of oil processing," China Oils and Fats, vol. 28, pp. 62-64, 2003 (Chinese).

[29] J. Sheehan, V. Camobreco, J. Duffield, M. Graboski, and H. Shapouri, Life Cycle Inventory of Biodiesel and Petroleum Diesel for Use in an Urban Bus, US Department of Energy's Office of Fuels Development, 1998.

[30] State Environmental Protection Administration of China (SEPA), Cleaner Production Standard-Edible Vegetable Oil Industry (Soya-Bean Oil and Soya-Bean Cake), SEPA, 2006.

[31] International P. GaBi 4.3 software. PE International, LeinfeldenEchterdingen, Germany, 2006.

[32] H. H. Khoo and R. B. H. Tan, "Life cycle investigation of $\mathrm{CO}_{2}$ recovery and sequestration," Environmental Science \& Technology, vol. 40, no. 12, pp. 4016-4024, 2006. 


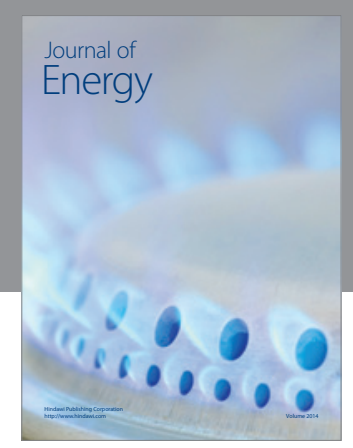

Journal of

Industrial Engineering
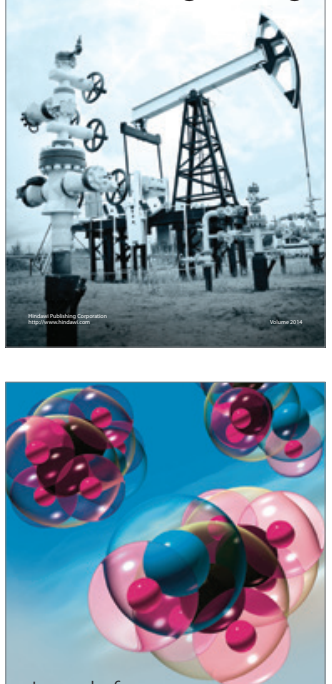

Fuels
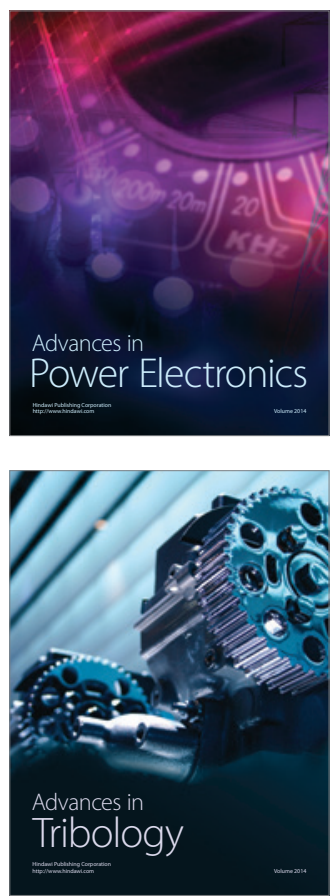

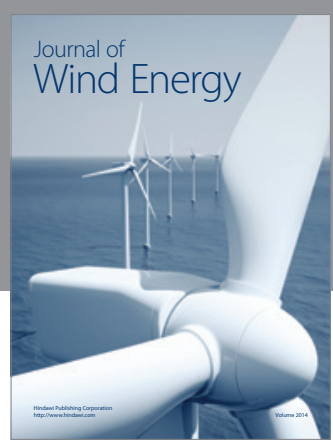

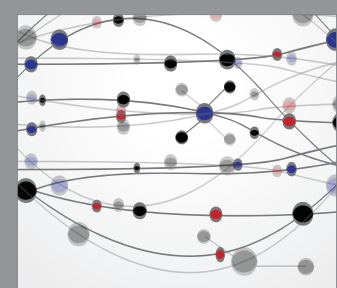

The Scientific World Journal

Submit your manuscripts at http://www.hindawi.com

Journal of

Structures
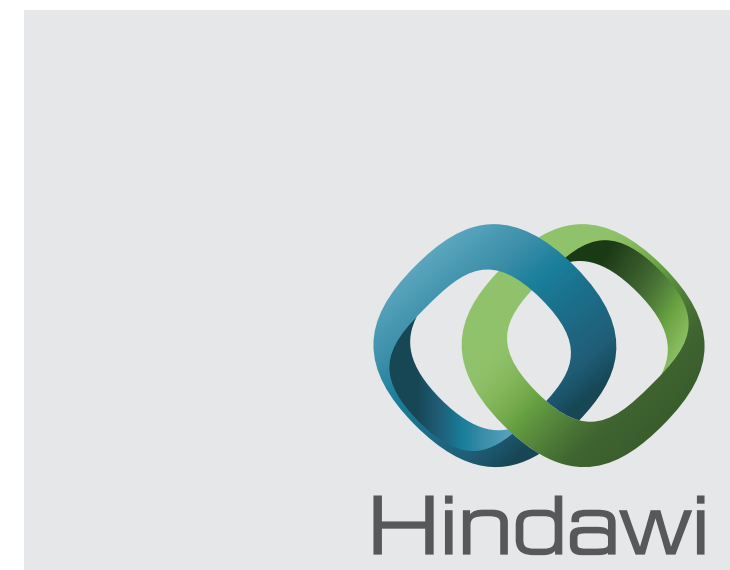

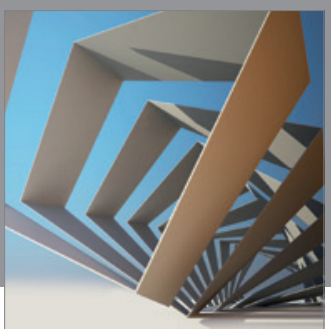

Rotating

Machinery
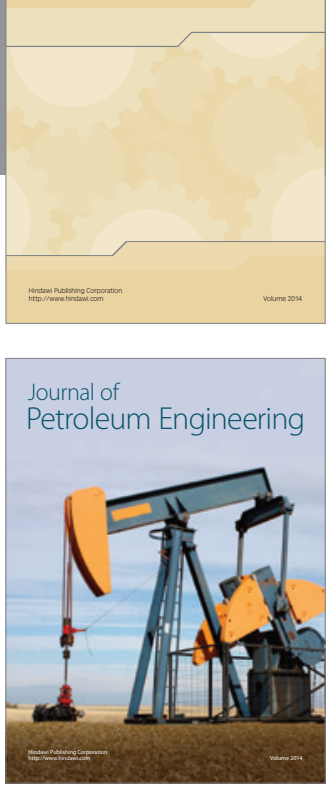

Journal of

Solar Energy
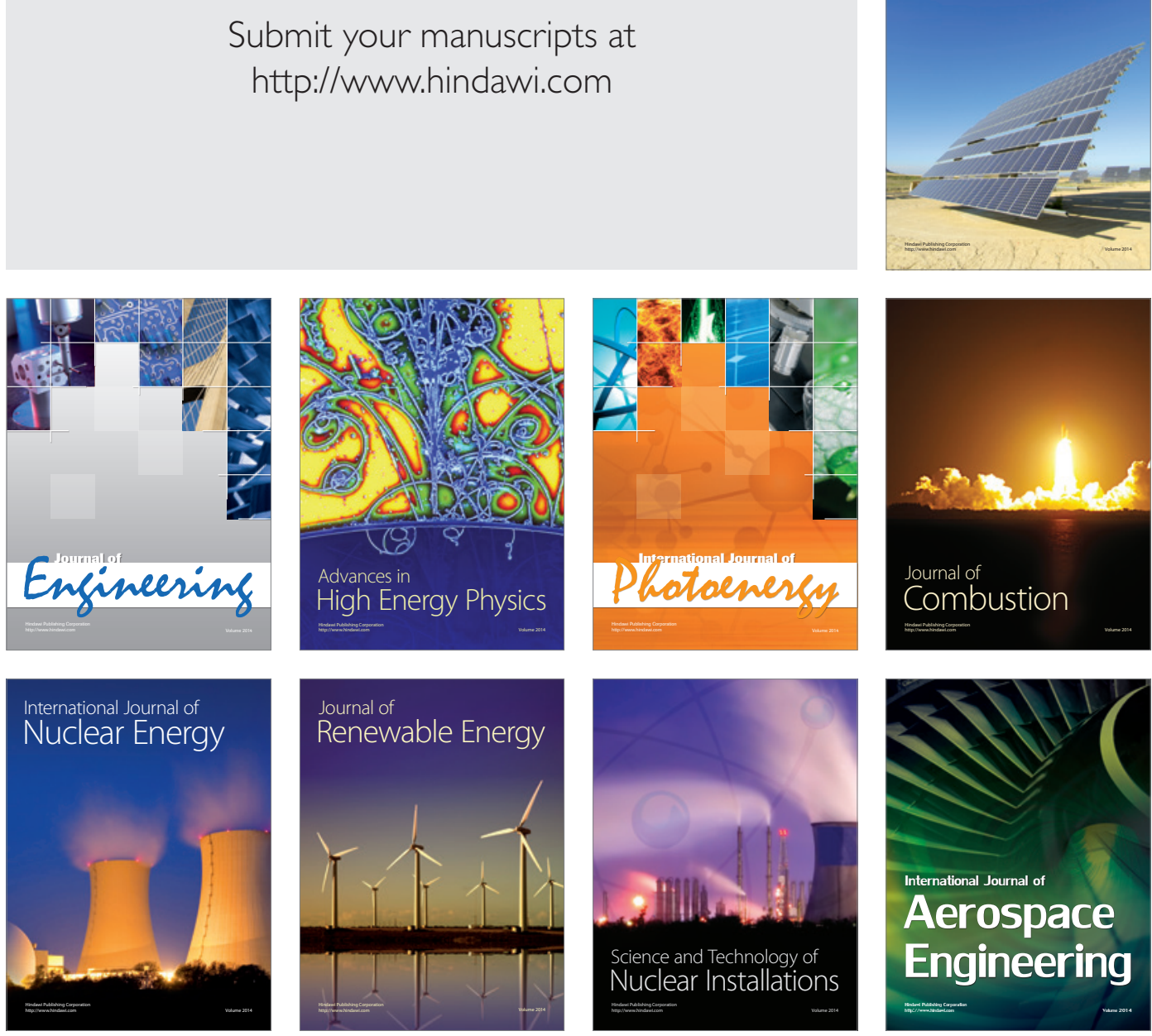